\title{
CLUSTER APPROACH TO REALIZATION OF INNOVATION DEVELOPMENT STRATEGY FOR THE AGROINDUSTRIAL COMPLEX OF THE REGION
}

This paper reviews cluster approach as an innovative management technology for the regional economy. The results of studying the theory and practice of clustering of the regional economy, the formation of agribusiness and food clusters in agribusiness are presented. Basic features and operation of the cluster systems are revealed and distinguished from other forms of cooperative and economic interactions between small and big business features, motivational components of integration into clusters.

On the basis of scientific propositions, a model of regional economic clusters is formulated; specific territorial distribution and level of aggregation of clusters in the agricultural sector were distinguished.

It is proposed to refer agroindustrial clusters to the clusters that represent the associations of organization of various fields in a single reproduction cycle from raw material to finished products sales including all stages of reproduction on the basis of innovation and investment activity.

A structuring work on principles of agro-clusters was held, sustainable competitive advantage and the formation mechanisms of the development of agro-industrial clusters have been grounded.

Keywords: agroindustrial complex, agroindustrial and grocery clusters

In the current economic conditions, the regional development strategies are basing on the achievements of science and innovation technologies. In this case the cluster approach is seen as an innovative technology of the regional economy management. According to M. Porter, whose theory of clustering was the most complete and has a systematic form, in the modern economy, especially in the context of globalization, the traditional division into sectors of the industry loses its relevance an clusters come first [4].

M. Porter believes that the country's competitiveness should be viewed through the lens of international competitiveness, not its individual firms but clusters - merges of various industries, and the ability of these clusters to effectively use internal resources is of fundamental importance [5].
The main result of the study was the establishment of M. Porter's well-known rhombus of competitive advantages of clusters consisting of four determinants: the conditions for the factors of production, the state of demand, related and supporting industries, sustainable strategy, structure and rivalry (goals, strategies, methods of organization, management companies and intra-industry competition).

In the scientific literature the main features of the cluster can be reduced to the «rule of four $\mathrm{C}$ »:

- Concentration of enterprises in one or allied industries in a geographic area;

- Competitiveness of their products;

- Competition to win and retain clients;

- Cooperation with a high level of incidence. 
There are three broad definition of clusters, each of which emphasizes the main feature of its functioning:

- Regionally limited forms of economic activity in related sectors, usually tied to particular scientific institutions;

- Vertical production chain, rather narrowly defined sectors in which the related manufacturing process forms the core of the cluster;

- A set of sectors on a higher level of aggregation (e.g. agro-industrial cluster).

In the western economic literature, clusters are structured in four groups of models:

1. Concentrated in a limited area competing companies that produce differentiated products and having a special marketing strategy abroad (European model).

2. Set of geographically concentrated firms with linked economic relations on the principle of territorial specialization (North American model).

3. Vertically integrated specialized area, established under the government's economic policy (Asian model).

4. Collection of small firms and organizations, centered around the organization of a monopolist, specializing in production of semi-finished goods by order of the parent organization and competing on price and quality for the right to deliver (Japanese model).

The first and second model involve intra-competition as the impulse of development, the third the leading and guiding role of the state, the fourth - the competition within the originally specified direction of development of the organization.

For a cluster the presence of competition of monopolies is requiredand the principle of free pricing, stability and responsibility of entrepreneurs. Acting as an integration mechanism, it allows firms to be more competitive.

Unlike other forms of cooperative and economic interactions of small and large businesses, cluster systems are characterized by the following features:

— presence of a large company leader, defining long-term economic, innovative and different strategy of the system;

- territorial localization of the bulk of business entities - participants in the cluster system;

- stability of economic relations of economic entities - participants in a cluster system, the dominant value of these bonds for the majority of its members;
- long-term coordination of the interaction of participants in the system as part of its production programs, innovative processes, the basic control systems, quality control etc.;

- factor of orientation on innovations: focus on the complex relationships between actors in goods and services and the subjects of innovations;

- leading (integrating) factor of the product or service. Often, a leading investor creates a cluster based on the newly created operating and restructured enterprises.

In the current economic conditions, it is possible to achieve business competitiveness, including agro-based industries, only through the introduction of the reproduction process of science, technology and innovation. The big innovation is usually impossible to achieve using the aspirations of a single business entity, one must bring together resource potential of the business, science, and to some extent, the authorities in the framework of the programtarget management. Practice shows that in most cases to obtain the necessary results of research and development, companies are cooperating in mutually beneficial forms of joint implementation and application of scientific and technological activities of research organizations, universities, other companies in the development and implementation of innovations.

The main reasons underlying the innovational cooperation are the division of costs, obtaining technological knowledge and mutual assistance in product development, new technologies, industry standards, obtaining additional markets, achieving increased speed of the market and others. Higher education in many countries provides research services in accordance with the power and the necessary equipment at much lower prices than commercial research organizations. The positive impact of clustering processes in the regions have on small and medium businesses. Motivational components for integration into the clusters are:

- survival and stability of development of small and medium-sized businesses, access to loans guaranteed by the company;

— possibility of using the infrastructure objects;

- participation in investment programs and projects (including the compensation of costs, fees for loans, investments and others).

Studies of the theory and practice of clustering the regional economy have enabled determination of what are the benefits of the cluster approach at 
the regional level and the economic viability of clusters.

Firstly, regional innovation clusters are based on the current stable distribution system for new technology, knowledge products, and the so-called technological network, which is based on joint the research based.

Во-вторых, предприятия кластера имеют дополнительные конкурентные преимущества за счет возможности осуществлять внутреннюю специализацию, минимизировать затраты на внедрение инноваций.

Third, an important feature of regional innovation clusters is the presence in their structure of flexible business structures - small businesses that allow creating innovative growth points of regional economy.

Fourth, regional innovation clusters are essential for the development of small businesses: they provide small businesses a high degree of specialization in servicing specific business niches, as this facilitates access to capital for a large company partner, as well as actively taking place to exchange ideas and knowledge transfer from professionals to entrepreneurs.

Distinctive features of the cluster of other associations are as follows:

- legal form - association (commercial partnership) - is a voluntary association of individu- als and (or) legal entities with a view to mutual cooperation, while maintaining their autonomy and independence;

- achievement of high quality standards;

- orientation of production for export;

- savings in procurement through collaboration with suppliers;

- reduction of transaction costs, the redistribution of production;

- collective brand, the joint distribution network;

- interaction of the cluster with the authorities.

With the cooperation of the regional administration with enterprises and research institutions, an increasing number of taxpayers and the tax base, there is a convenient tool for interaction with business, reduced dependency on vertically organized business groups, there are grounds for diversification of the economy and solving social problems in the regions.

Basing on these scientific statements and guidelines, we formulated a general model of regional economic clusters (Fig. 1).

In the proposed model, the following structural elements are defined:

1) the core - industrial companies with regional specialization in producing end products, including agricultural processing enterprises;

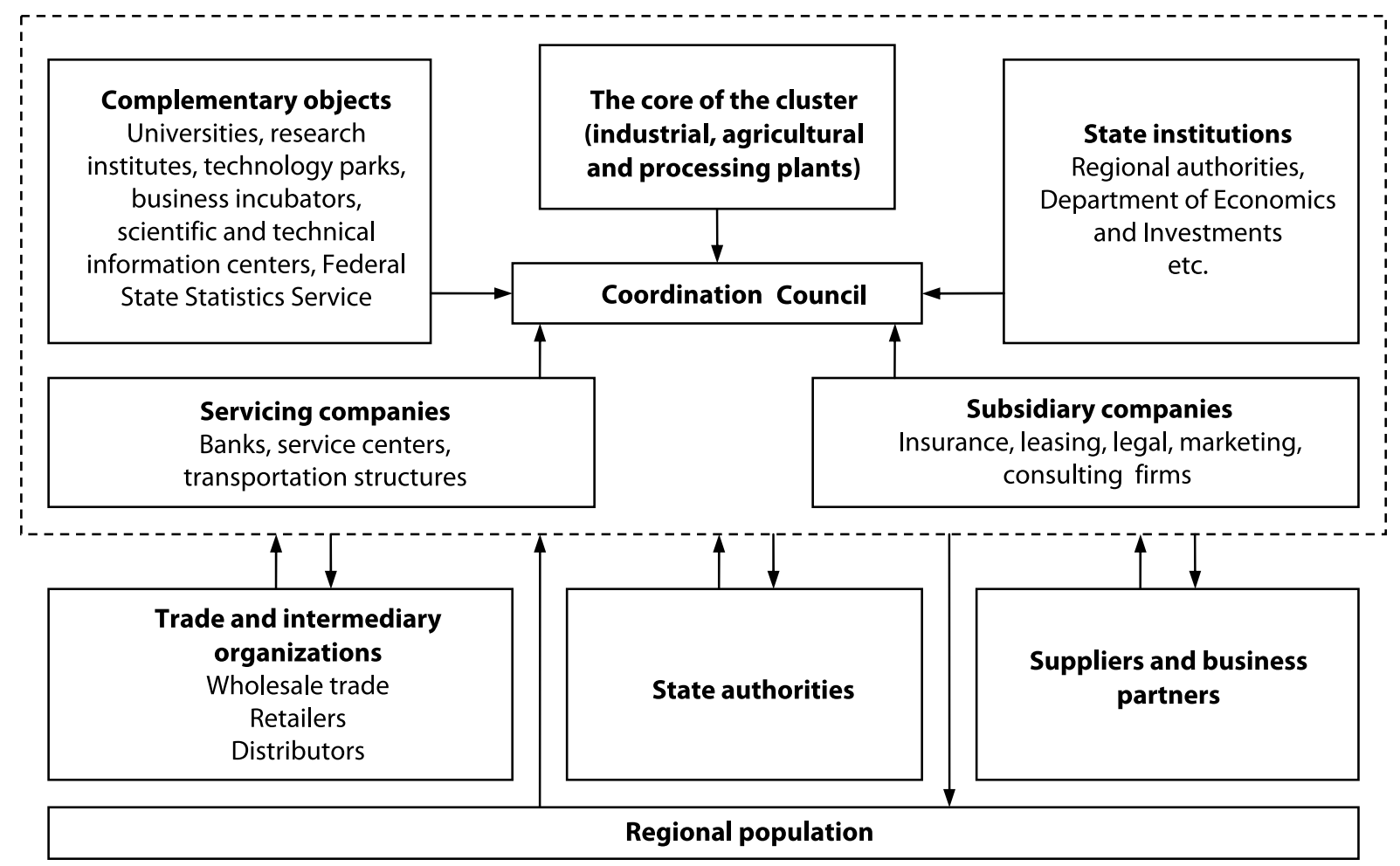

Fig. 1. Model of a regional economic cluster 
2) complementary objects - objects whose activities are directly operates the industry;

3) service facilities - objects whose presence is required, but their activity is not directly related to the functioning of industrial enterprises;

4) supporting objects - objects of the cluster which are desirable for the operation of the cluster.

In turn, it is appropriate to divide regional economic clusters into groups of industrial production and food clusters. In particular, there is specific spatial location and a higher level of aggregation of different clusters in the agricultural sector. It seems possible to determine the agro-industrial cluster in today's Russia as a combination of spatial organization of production and marketing activities in order to increase competitiveness and investment activity in agriculture and agroindustrial complex.

Agroindustrial clusters are clusters that represent the associatiative organizations of various fields in a single reproduction cycle from raw material to finished products are sold to include all stages of reproduction on the basis of innovation and investment activity.

The purpose of the agro-industry cluster subdivision may be the grocery marketing aspect: retention of market share, occupation of the free market niche in a certain area with a competitor and others. As part of the agro-industrial cluster, transport companies, manufacturers of agricultural machinery, agricultural and processing organizations must be present [3, 4], agro-industrial holding companies (corporations), consulting organizations, research and design institutes, educational institutions, legal institutions, governments and financial institutions.

Attempts to establish agro-industrial clusters were undertaken in Kaliningrad, Belgorod, Rostov, Samara, Krasnoyarsk and Altai territories and some other regions of the country. As world practice shows, combination into clusters is useful for those who work on creation of the final product. In the traditional agro-industrial integration, the bulk of profits remains at the output of the final product. The cluster approach also creates a mechanism for the relationship, which allows one to receive the equivalent cost profit not only to the person who makes or sells the final product, but also all members of the cluster. This is one of the essential differences from the existing cluster of integrated structures, including agricultural holdings, financial and industrial groups in which economic relations of the participants are not equivalent.
The designated principles reflect the design features of cluster structures in the present conditions of economic development and the specific development of agriculture in the region, including Altai region. Structuring principles of agro-industrial clusters are shown in the Table.

Cluster structures in the region require appropriate governmental policy. According to the role of the state, there are four types of cluster policy:

1. Catalytic cluster policy, when the government brings interested parties together and provides limited financial support for the project.

2. Supporting cluster policy, in which the catalytic function of the state is complemented by its investments into regional infrastructure, education and marketing to promote the development of clusters.

3. Directive cluster policy, when the supporting function of the state is supplemented by special programs aimed at transforming the specialization of regions through the development of clusters.

4. Cluster interventionist policy, when the government, along with the implementation of its policy-making functions from the private sector, takes over the responsibility for making decisions on the further development of clusters and through transfers, subsidies, restrictions or regulations, as well as the active control of firms in the cluster and creates its specialization [2].

According to a study performed by M. Enright, in $40 \%$ of the 160 regional clusters developing in the world today, the municipal and regional authorities carry out maintenance cluster policy.

At the systemic problems in agriculture there is an objective need for a clear socio-economic structure of agriculture, within which one will undertake the development of forecasts and development programs for each specific product cluster of the region. Since at the regional level the inertia of the processes is lower than at the macrolevel, the abovementioned features of operational decisionmaking and maneuvering means and the relationship of economic, political and other management decisions with social processes are revealed more clearly. In this case, the order parameter in the public system should act as the regulatory activities of the state of the economy.

We believe that the concept of regional agricultural development and formation of included into it food clusters can successfully compete in crisis time with a large share of food imports and is the most effective economic and social basis for con- 
Principles of building clusters in agroindustrial complex of the region

\begin{tabular}{|c|c|}
\hline Principles & Content \\
\hline Self-organization & $\begin{array}{l}\text { 1. Historical background of cluster development } \\
\text { 2. Structural and functional community of cluster enterprises } \\
\text { 3. Enhancing the linkages of enterprises inside the cluster } \\
\text { 4. Creating conditions for cluster development and formation }\end{array}$ \\
\hline $\begin{array}{l}\text { Intra-cluster coopera- } \\
\text { tion and concurrence }\end{array}$ & $\begin{array}{l}\text { 1. Competition between enterprises } \\
\text { 2. Cooperation in entering the regional market } \\
\text { 3. Efficiency and development of own business } \\
\text { 4. Stimulation of innovational processes }\end{array}$ \\
\hline $\begin{array}{l}\text { Interaction and inter- } \\
\text { relation based on joint } \\
\text { economic interests }\end{array}$ & $\begin{array}{l}\text { 1. Dependence of participants on each other's success } \\
\text { 2. Increased business innovation } \\
\text { 3. Preservation of cluster participants' autonomy and solidarity } \\
\text { 4. Coordination, resolution of disputes and decision-making, establishment of external relations }\end{array}$ \\
\hline Corporativity & $\begin{array}{l}\text { 1. Culture of communication between the participants, presence of a climate of trust } \\
\text { 2. Reciprocity and good-neighborliness, values, behavior patterns, ways of assessing mutual control in } \\
\text { conflict resolution } \\
\text { 3. Opportunity to share information, experiences, joint training } \\
\text { 4. Simplifying the structure of the interaction, reducing costs }\end{array}$ \\
\hline $\begin{array}{l}\text { Long-term } \\
\text { collaboration }\end{array}$ & $\begin{array}{l}\text { 1. Maintaining relationships } \\
\text { 2. Regular, long-term assurance of supply and quality of services } \\
\text { 3. Access to information, resources, knowledge of participants } \\
\text { 4. Interaction to achieve and maintain competitive advantage }\end{array}$ \\
\hline Partial leadership & $\begin{array}{l}\text { 1. Presence of the «center of attraction» (structure-building companies-leaders) } \\
\text { 2. Dominant factor is concentration around major leading industrial companies and research centers } \\
\text { 3. Manifestation of the activity of the «center» and attraction of «peripheral» businesses }\end{array}$ \\
\hline Dynamism (flexibility) & $\begin{array}{l}\text { 1. Constant «movement» of the cluster - continuous process of formation, development and decay } \\
\text { 2. Adaptation to the changing needs of the market environment } \\
\text { 3. Emergence of new industries and expanding the product range } \\
\text { 4. Increasing the level of innovative production }\end{array}$ \\
\hline $\begin{array}{l}\text { Complexity of re- } \\
\text { sources usage }\end{array}$ & $\begin{array}{l}\text { 1. Combining participants into single unbroken process chain, integrational and technological inter- } \\
\text { dependence, single technological approach and standards } \\
\text { 2. Sequence of production, the participants are suppliers and consumers of each other's goods services } \\
\text { 3. Focusing on end-user needs, expanding the product range } \\
\text { 4. Improving business processes and management skills }\end{array}$ \\
\hline $\begin{array}{l}\text { Outsourcing } \\
\text { specialization }\end{array}$ & $\begin{array}{l}\text { 1. Delegation of responsibility, fragmentation of business functions } \\
\text { 2. Transfer of auxiliary facilities on contracts to contractors, reducing costs and saving resources } \\
\text { 3. Formation of new unique abilities, access to the best production technologies }\end{array}$ \\
\hline
\end{tabular}

septual foresights. At the same time, the cluster selection as the criterion for recognizing the object of planning and forecasting are the organizational and economic relations with the movement of product from its initial raw material stage to final product needed to meet consumer demand.

Grocery cluster is a voluntary association of all structural elements with economic and social interest in the manufactured product that provides competitive advantage, technical, organizational, managerial and social problem solving. The main integrators are agricultural producers, including their association as a source for the formation of raw materials for processing industry. Joint activities of producers and processors will eventually be a point of growth, and linking elements - the representatives of infrastructure links, science and edu- cation, administrative authorities. Mechanism for implementing the control functions of the cluster structure should be the innovation of all participants (Fig. 2).

In our point view, the cluster approach is grounded in positive synergistic effects of regional agglomeration, i. e. proximity to the consumer and producer, network effects and diffusion of knowledge and skills due to migration of staff and allocation of business. There are no boundaries between sectors and activities and they are all considered in conjunction.

For governments: the number of taxpayers and the tax base (control centers for small and mediumsized businesses, as a rule, are in the same area, as opposed to vertical corporations) is increasing, there is a convenient tool for communication, reduced de- 


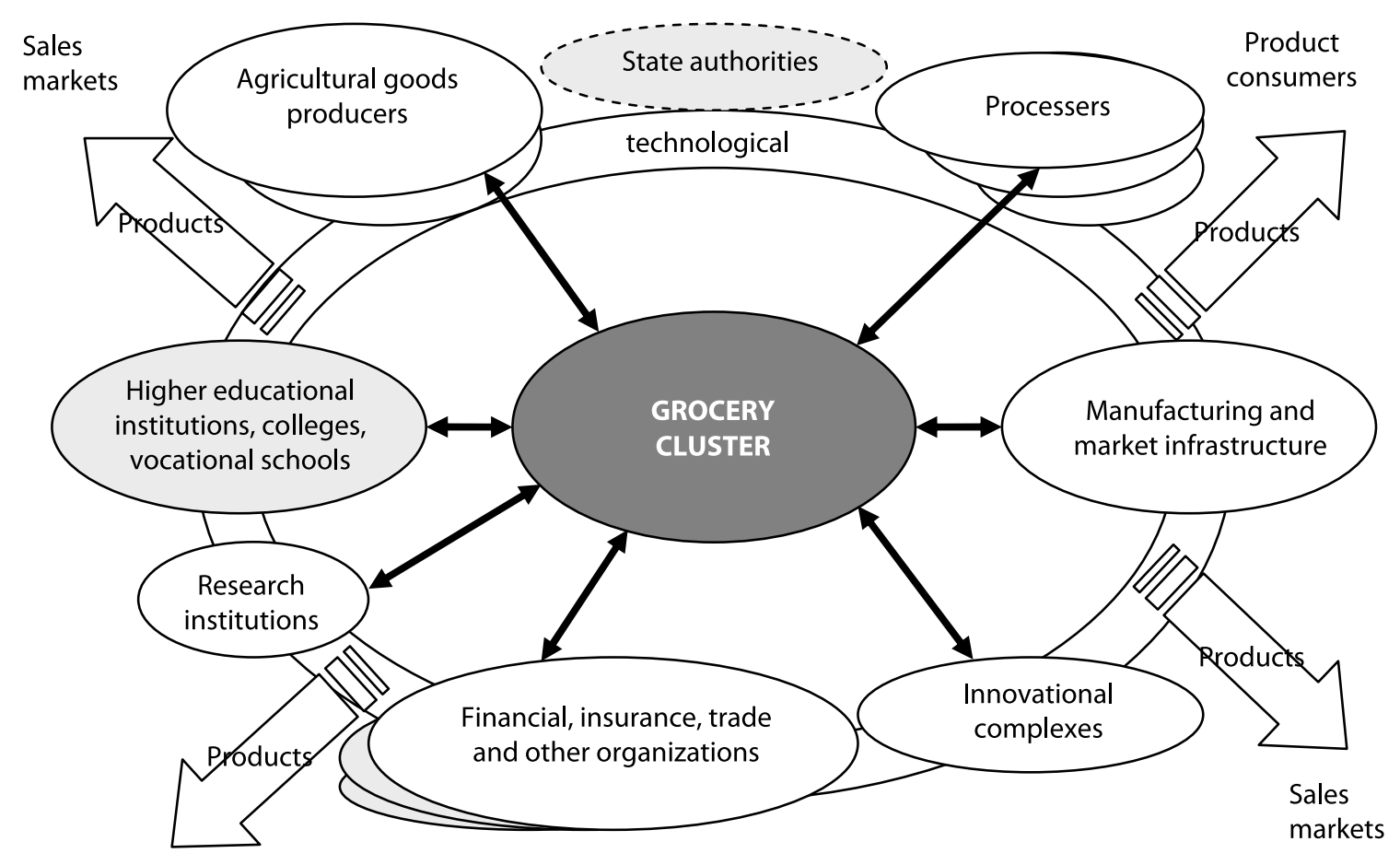

Product consumers

Fig. 2. Grocery cluster of the regional agroind ustrial complex system

pendence on the individual business groups, there are grounds for diversification of economic development. For the business: infrastructure and personnel for research and development is improving, costs are getting lower and there are opportunities for a more successful entry into international markets.

The necessity and significance of the structure of the regional agricultural cluster technologies supported by such well-known projects in the world, as the wine cluster in California (USA) and Baden-Wuerttemberg (Germany), soy-corn and grain belt of clusters in the U.S. and Canada, the clusters for the production of cheese and chocolate in Switzerland etc. Consequently, in the grocery subcomplex (sugar beet, grain, meat, dairy, etc.) is it necessary to create competitive regional agribusiness clusters based on the agricultural and processing enterprises (economic core) and then at the level of agricultural Russia - inter-regional economic clusters. In these economic core regions represents the set of poles of growth. Territory of the regional economic space, where the raw material producers and processors act as poles of the concentration of factors of production and capital to ensure an effective return on investment within the region as a whole and the cluster in particular.

Clustering of the Russian economy at the grocery subcomplexes level of the agroindustrial complex of the regions is an objective necessity in times of crisis to ensure food security and to strengthen both regional and national competitiveness, since the product clusters represent an optimal combination of market opportunities, selfregulation capabilities of state influence. The synergetic effect caused by these interactions is able to identify and strengthen traditional new growth point of regional economy.

Science and practice show that the formation of regional economic clusters in agriculture has economic and social feasibility, considering the the backlog of Russian agriculture in the level of intensity and efficiency. We have carried out research and development of a cluster model of the regional economy and the formation of regional agro-clusters. In Altai region, there are actively functioning biopharmaceutical, medical and engineering clusters. In the stage of model development and organization are grocery clusters, horticulture, sugar beet production, corn-grocery and agrotouristic clusters.

In our view, cluster approach is grounded in positive synergistic effects of regional agglomeration, i. e. proximity to the consumer and producer, network effects, the diffusion of knowledge and skills due to migration of personnel and the allocation of business.

Altai Biopharmaceutical Cluster (ABFC) «Altaibio» - involves the allocation of the core (inner contour), which consists of JSC «Evalar» and 


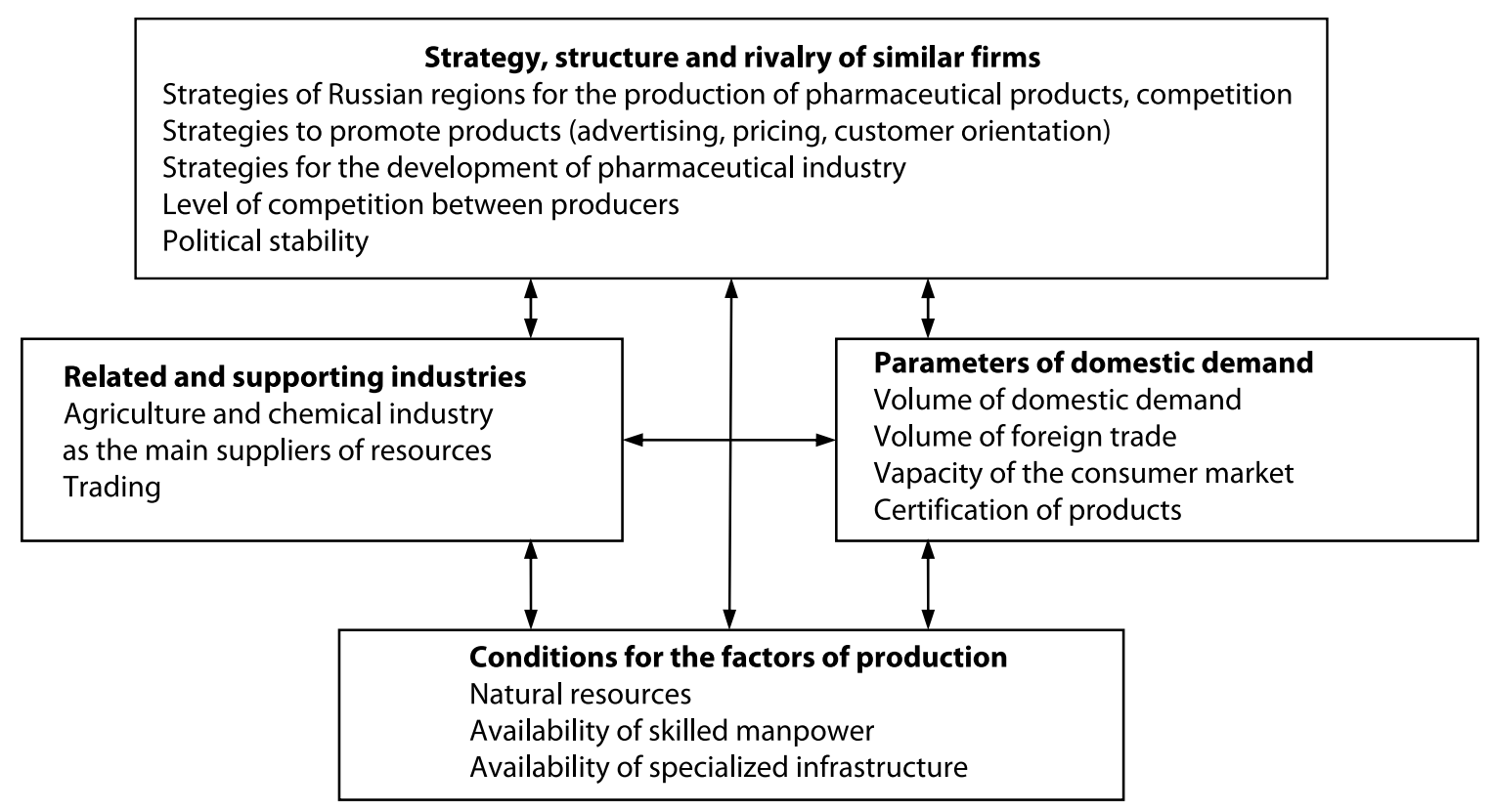

Fig. 3. Determinants of the concurrent advantages of the ABFC

JSC «Altayvitaminy», and others, as well as the external environment (external contour).

The highest governing body of ABFC is the general meeting of members of the cluster. The main function of the general meeting is ensuring compliance with partnership objectives for which it was created. To guide the everyday activity of ABFC, between the general meetings, the board cluster shall be elected - a permanent collegial management body (according to the site of the Altai Biopharmaceutical Cluster «Altaibio» - http:// www.altaybio.ru/). For participants in the cluster «Altaibio», there are two main problems.

The first one is to create a portfolio of quality Russian generic pharmaceuticals. The second one is to create absolutely news Russian pharmaceuticals.

Structurally, the production cluster consists of three components: chemical and pharmaceutical production, biopharmaceutical manufacturing and grocery production with given useful properties. Profits from the production of only one new pharmaceutical, «Malawi» was 34.1 million rubles in 2009, 33.8 million rubles in 2008 and 24.6 million rubles in 2007. Total profit before taxation generated from the production of the pharmaceutical «Malawi» is equal to 168 million rubles.

Natural competitive advantages of the cluster are biopharmaceutics and bioparapharmaceutics - directions based on the use of unique natural resources of Altai. In the manufacturing process of the pharmaceutical «Malawi», the results of innovational work of the participants of the cluster are used.
The development objectives of the ABFC are closely connected with with the Development Strategy of the pharmaceutical industry of the Russian Federation «PHARMA-2020», under which Altai region is considered an important region in the pharmaceuticals production (according to the Altai Biopharmaceutical Cluster «Altaibio» — http://www.altaybio.ru/).

Concurrent advantages of the ABFC are shown in Fig. 3.

The main thing that is given by the clusters is an opportunity for businesses and the economy of the region to develop in an innovative, not inertial way. For the business, a cluster is a real opportunity to secure future competitiveness and attract investments. However, it is important to understand that clusters can produce results only if they fit into the broader context of regional development strategies.

Our studies show that organization of integrated structures on the basis of cluster approach promotes development of innovative processes, improves investment climate in the branches of grocery subcomplex and agroindustrial complex in the region, i.e. increases its competitiveness.

In order to determine the results of cluster policy, methodological approaches are being developed. Program-targeted management based on the cluster approach involves cluster analysis [1]. The cluster analysis allows to consider a sufficiently large amount of information: improvement of the basic indicators of industrial and economic activity (sales, profitability, capital productivity, etc.), 
increase of tax revenues, increase of the volume of attracted investments, including foreign enterprises and increase of the number of organizations participating in the cluster, increasing the share of small and medium-sized enterprises in a cluster share, the share of an intellectual product in the production of cluster, the number of skilled jobs and other indicators, depending on the options promoted by the cluster and the tasks.

In the cluster analysis, along with traditional, economic-mathematical methods, including mathematical statistics, optimization, construction of dendrograms based on the ideology of interbranch bal- ance are applied. In the process of cluster analysis in the field of agriculture, the inclusion of such factors as soil quality and changes in demand and their impact on industrial location and specialization is done. The analysis of the remaining conditions, including combined effects of supply and demand, local differences in wages and prices, scorecards, which takes into account the totality of the factors of production location was also carried out.

As a result, the use of cluster approach and cluster analysis allows provision of effective management of the strategic development of the region's economy.

\section{References}

1. Kotova E. S. (1999). Klasternyy analiz v zadachakh sotsial'no-ekonomicheskogo prognozirovaniya: uchebnoe posobie. Moscow: Moscow State Institute of International Relations Publ.

2. Negreev D. Altayskiy biofarmatsevticheskiy klaster. Referat na populyarnuyu temu [Altai biopharmaceutical cluster. Summary on the popular theme]. PolitiSib.Ru [PolitiSib.Ru]. Retrieved from: http://www.politsib.ru/news/?id=32146

3. Pilipenko I. V. Provedenie klasternoy politiki v Rossii [ Prilozhenie $6 \mathrm{k}$ Ezhegodnomu ekonomicheskomu dokladu Obshcherossiyskoy obshchestvennoy organizatsii «Delovaya Rossiya» «Strategiya 2020»: ot ekonomiki «direktiv» k ekonomike «stimulov»] // Podkomitet TPP RF po razvitiyu subkontraktatsii i klasternykh tekhnologiy. [Conducting Cluster Policy in Russia [Annex 6 to the Annual Economic Report - Russian public organization «Business Russia» «Strategy 2020»; From the economy of «directives» to the economy of «incentives»]. Subcommittee of the Chamber of Commerce and Industry on development of subcontracting and cluster technologies.] Retrieved from: http://promcluster.ru/images/UPLOAD/pilipenko_i_v\%20klast\%20 polit\%20in\%20russia\%20-\%202008.pdf

4. Porter M. (2005). Konkurentsiya [Competition]. Moscow: «Vil'yams» Publ.

5. Porter M., Shchetinin V. D. (Ed.) (1993). Mezhdunarodnaya konkurentsiya [International Competition]. Moscow: Mezhdunarodnye otnosheniya [International Relations].

6. Romanov A. E., Arashukov V. P. (2008). Agropromyshlennye klastery Rossii - novyy mif ili perspektiva? [Agroindustrial clusters of Russia - a new myth or a prospect?]. Ekonomika sel'skokhozyaystvennykh i pererabatyvayushchikh predpriyatiy [Economics of agricultural and processing enterprises], 7, 27-33.

7. Teplova I. G. Klastery kak instrument regional'noy politiki. Na primere Altayskogo biofarmatsevticheskogo klastera [Clusters as a tool of regional policy. On the example of the Altai biopharmaceutical cluster]. Retrieved from: http://www.sitebs.ru/blogs/745. html

\section{Information about the author}

Kundius Valentina Aleksandrovna (Barnaul) - Doctor of Economics, Professor, Honored Worker of Higher School of Russia, Vice Rector for Innovational Work, Head of the Department of Economics of the Agroindustrial Complex at the Altai State Agricultural University (656049 Barnaul, Krasnoarmeiskiy pr-t 98, Altai State Agricultural University. Tel.: +7 (3852) 62-83-51; e-mail:kundiusv@mail.ru). 